\title{
Digital Literacy Qualitative Analysis in Vocational Teachers
}

\author{
Saripudin S 1), S.Sumarto ${ }^{1)}$, E.A Juanda ${ }^{1)}$, Ade Gafar Abdullah ${ }^{1)}$, Ana A ${ }^{1)}$, Tutin Ariyanti ${ }^{1)}$ \\ ${ }^{I}$ Technology and Vocational Education Study Program, Post Graduate UniversitasPendidikan Indonesia \\ bangsarip@upi.edu
}

Keywords: $\quad$ digital literacy, learning media, vocational teachers

Abstract: $\quad$ The challenges of digital media in learning today are demanded better by the demands of the digital era which are increasingly high in people's lives today. Teachers provide teaching materials with traditional learning media which certainly has an impact on the asking and motivation of students in accepting and developing these lessons. So that teachers are demanded of digital development nowadays to be able to literate digital media in learning. For this reason, this study aims to reveal the digital literacy of teachers in the use of instructional media in the classroom. The research method used is a qualitative descriptive method. Taking research subjects using purposive sampling method. The main instrument in this study was the researchers themselves who were assisted by assistive instruments in the form of depth interview guides. The study was conducted on 4 Vocational Schools consisting of 1 Vocational School in the City of Bandung, 2 Vocational Schools in West Bandung Regency,and 1 Vocational School in Bekasi Regency. The subjects of this study were productive teachers who were in the Vocational School totaling 6 teachers. This interview wanted to reveal about the types of digital media use inside and outside the classroom, the reasons for using digital media, how to use digital media and the obstacles experienced by teachers in using digital media. This research hopes to provide recommendations to vocational teachers, especially productive teachers in digital literacy, the use of learning media in schools and policy makers in schools to support digital facilities that support the learning needs of teachers and students in schools.

\section{INTRODUCTION}

In the 21st century, the explosion of digital technology devices has greatly increased its use of various purposes in the work place as well as education both formal and non-formal (Kumar Basak, S., Wotto, M., \&Bélanger, P. 2018, Abdelmoiz Ramadan et, al , 2018, Göksün, DO, \& Kurt, AA 2017). The improvement of digital media in schools is very dependent on the teacher's positive skills and attitudes towards the developed learning objectives (Utakrit, N., \& Saelee, S. 2017). Like the development of learning including electroniclearning (e-learning), mobile-learning (e-learning), and digital-learning (d-learning). Kumar Basak, S., Wotto, M., \&Bélanger, P. 2018 state that students and teachers need to acquire technological skills and innovative approaches to master the E-learning, Mlearning and D-learning environment successfully. The type of teacher learning media greatly influences the teacher's approach to teaching (Law, US, \& Stock, R. 2017).

The development of digital technology Information technology (ICT) has greatly affected all areas of people's lives (Abdelmoiz Ramadan et, al, 2018). With the initiation of media technology in the 21 st century, a teacher cannot survive with the ability to teach traditionally with ordinary media without looking for new technological information and aditionally, digital literacy has become an important part of learning (Göksün, DO, \& Kurt, AA 2017). In the digital era, teachers are required to be able to interact with the world of ICT because literacy with ICT is expected to have critical thinking about skills to support the use of technology in the learning process in the classroom (Lim HooiLian, et al, 2014). In addition, the internet has now provided many services as a tool to be able to access student learning both inside and outside the classroom (E-safety Support, 2013). There are many factors that influence the literacy of ICT teachers, including age as well as supporting ICT infrastructure for teachers (Abdelmoiz Ramadan et, al, 2018).

Teachers in the digital era are expected to be able to introduce students to the use of multimedia (Amy Hutchison, 2018). In addition, teachers are also expected to be able to integrate ICT in the learning process in a creative way, so that students can be involved in audio, text and video to improve student learning skills (Baxa, J., \& Christ, T. 2018).

Therefore teachers' literacy on ICT is an important part to be improved as it will affect the teaching process and play an important role in the world of education. This study will examine qualitatively how teachers explore the ICT literacy in the use of ICT in the teaching process. 


\subsection{The Importance of Digital Literacy}

Indonesia is one of the countries with the largest number of internet users in the world. According to the results of research conducted by the Indonesian Internet Service Providers Association (APJII) together with the University of Indonesia's Communication Study Center (Puskakom), the total number of Internet users in Indonesia as of early 2015 reached 88.1 million people. Thereafter, according to research reported by wearesocial.sg in 2017 there were 132 million internet users in Indonesia and this figure grew by 51 percent in one year (Ministry of Education and Culture, 2017). This shows that information technology is growing rapidly in line with the demands of the current era, especially with the demands of the 21 st century digital era (Zhao, 2018)

Digital literacy is currently needed in all aspects of human life, especially in the world of education. A teacher who is resistant to the development of this digital era will experience setbacks in the learning process. In the digital age, some experts argue that digital literacy teachers are demonstrated through critical thinking skills in order to support the use of digital technology (Hague and Payton, 2010). Another opinion states that internet services could assist teachers in finding learning resources, providing teaching concept, and giving remote classroom access. It also supports students in accessing teaching materials (E-safety Support, 2013).

Thus the importance of digital literacy means more than helping students with the use of digital technology but also facilitating students to absorb teaching and learn the skill concept. In addition, teachers also need digital literacy to support learning skills. Julien and Genuis (2011) consider that digital literacy is the basis for improving academic achievement, providing more active student involvement and finding the effective information.

\subsection{Digital Literacy of Vocational Teachers}

Digital literacy is a skill that shows a person's ability to search, organize, evaluate, and analyze information using digital technology (FazilatShidiqet, al. 2016). Digital literacy has become an important part of teacher competence. Gruszczynaska et al. (2013) states that there are two things needed to get teacher's attention related to digital literacy, including the skills to use digital and its practical skills. Hague and Payton (2010) state that there are eight (8) components of digital literacy required to be acquired by teachers as follows:

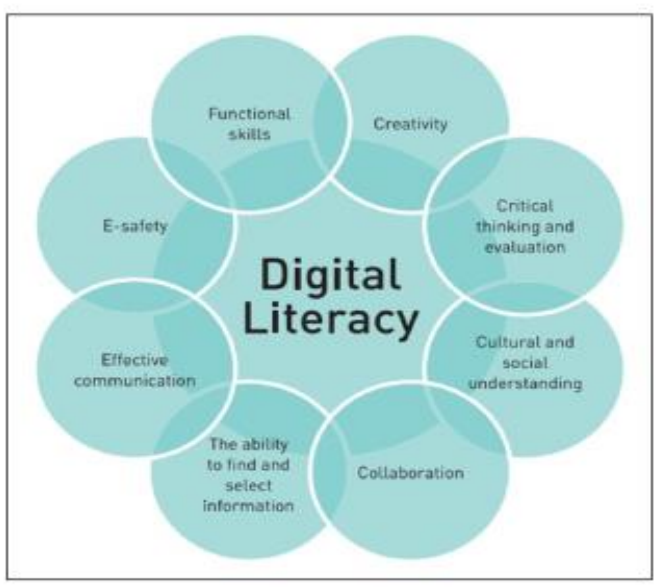

Figure 1. The components of digital literacy.

1. Functional skills: the abilities and confidence in using technology;

2. Creativity: the ability to create products creatively with digital technology;

3. Collaboration:the ability to collaborate with students in developing strategies for developing digital technology;

4. Communication: the ability to communicate with students at any time online;

5. The ability to find and select information:the ability to provide clear instruction to students in finding relevant information in line with learning materials;

6. Critical thinking and evaluation: the ability to facilitate students to ask questions and do some creative work

7. E-Safety: the ability to support children to be more competent in using digital technology.

Of the eight components above, what needs to be considered by teachers arethe suitable tools needed in the learning process so that the active role of students can be achieved.

The school support affects directly to the use of teacher digital media. ICT is a globally recognized tool that needs to be fully integrated in all fields of education, especially vocational schools, considering the sophistication of this technology continues to evolve and one of them affects the development of Human Resources (HR), industry and people both in the public and private sectors.

Even though effective ICT integration in Vocational Schools can be performed, there are also some limitations from either material or human sides. The challenge in the development of ICT in the world 
of education is the ability of teachers to integrate ICT in learning (US Department of Education (2001).

Teachers must be able to encourage and instill teaching and learning for creativity, critical, innovative thinking and high-level thinking skills rather than conceptual and procedural knowledge, as well as knowledge memorization. This application has been carried out in Malaysia, given the need for cultural changes in assessment towards the application of ICT (Lian, LH, 2014).

Digital classes have been proven to produce pedagogical design and development of information literacy competencies and critical thinking skills for both students and teachers (Kong, SC (2014). In addition, ICT literacy provides convenience, innovation and creates active learning for students to encourage improvement of competence, abilities and knowledge of students in practicum (Brok, LS (nd), 2008) A. Khalkhali, et. Al., 2008). Basically, ICT provides convenience to be accessed anytime and anywhere. In addition to active learning, ICT literacy is able to provide independent learning for students (Peer, S., Goldman, D., \&Yavetz, B., 2007). Teachers must be able to provide ICT literacy innovations so that students are more interested and continue to develop their abilities (Olofsson, A.D et. Al., 2015)

\subsection{Teacher's Digital Competence}

Digital competencies are capabilities related to computer and internet use including hardware operating skills, web navigation, editing skills, and online exploration (Aesaert, et.al, 2015). Digital competencies are related to the ability to access, manage, integrate, evaluate, and make information (Zylka, et.al, 2015). More technically, digital competence is related to computer literacy skills (technical abilities), information and communication literacy skills; which consists of creative use of information, evaluating information, and exchanging information (Claro et al., 2012). The scope of digital competence in the context of learning includes the dimensions of knowledge, skills, and attitudes. Knowledge aspects include professional literacy skills and digital integration into teaching. Skills aspects include skills using digital applications and integrating skills into learning. Attitude aspects include digital knowledge, digital learning, and digital applications (Wen \& Shih, 2008). Digital competencies can be identified from five aspects, namely the ability to access, manage, integrate, evaluate, and create (Panel, 2007). The ability of teachers to apply digital in classroom learning includes knowledge of teaching content and didactic content knowledge (Kubrický\&Č́stková, 2015a).
Digital implementation in learning needs to pay attention to several aspects, namely Knowledge Technology (TK), Pedagogical Knowledge (PK), and Knowledge Content (CK), which are interrelated to form comprehensive digital competencies (Martinovic\& Zhang, 2012)). Digital implementation in learning will be influenced by education policy, infrastructure, digital literacy, and learning conditions (Sánchez \& Salinas, 2008).

The parts of the research related to the expected competencies are shown in Figure 2 below:

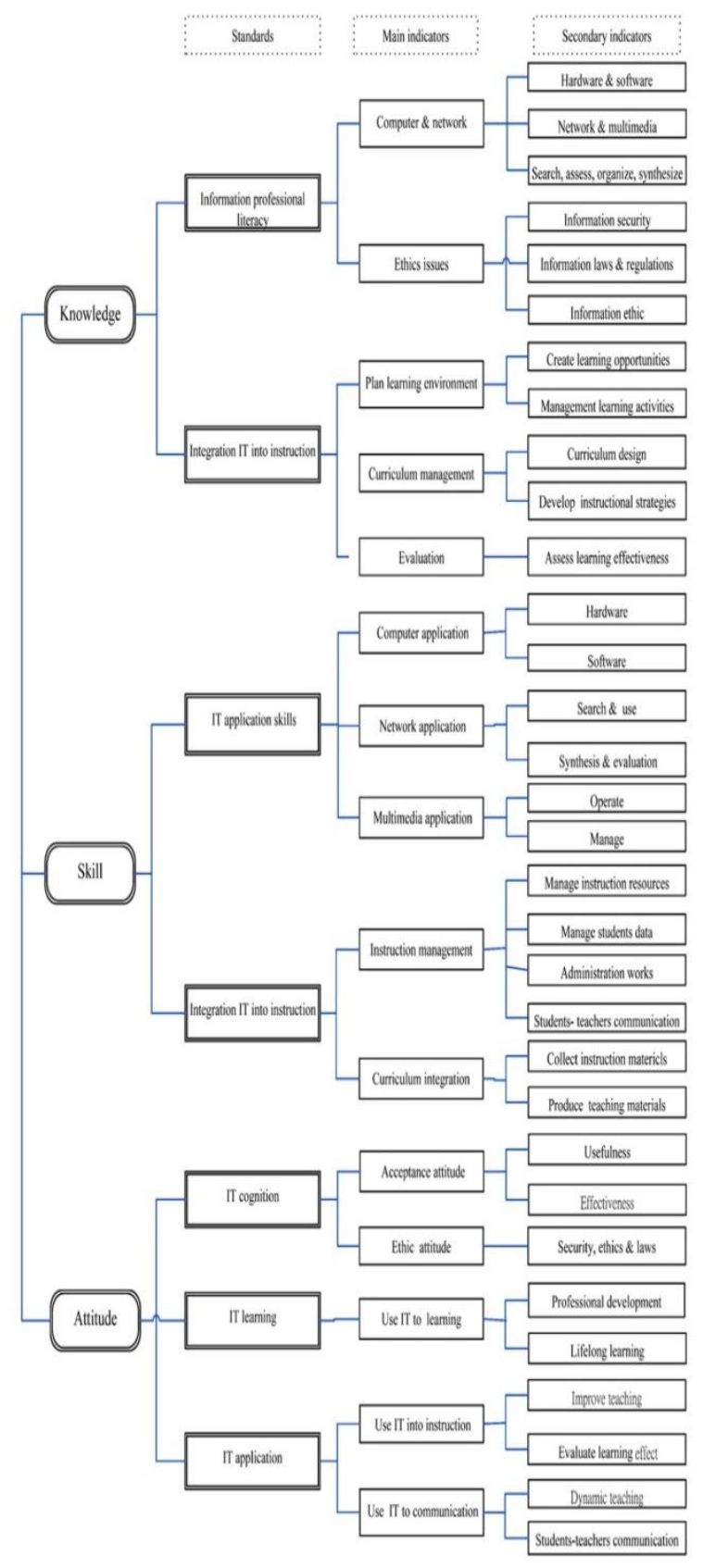

Figure 2. ICT Literacy Measurement Component 


\section{METHODOLOGY}

This research is a qualitative type of research (Borg and Gall, 1989) which describes the ICT literacy skills of Vocational Teachers in the learning process. Purposive sampling method was used in determining sampling criteria. The main instrument in this study was the researchers themselves who were assisted by assistive instruments in the form of depth interview guides. The study was conducted on 6 Vocational Schools consisting of 1 Vocational School in Bandung City, 2 Vocational Schools in Kab. West Bandung, 1 Vocational School in Kab. Bandung and 1 Vocational School in Kab. Bekasi. The subjects of this study were 9 productive teachers.

Data collection used the method of observation and interviews (Polit and Beck, 2006; Fontana and Prokos, 2007). The interviews used were structured and semi-structured interviews. Structured interviews refer to interview guidelines. Shall some information arise needs to be studied in depth, then semistructured interviews are conducted. The research questions in this study related to the types of digital media that teachers use, usage procedure, teachers' rationale, and the barriers to ICT literacy of vocational teachers in the learning process.

\section{RESULT}

The results of the interviews to six vocational school teachers regarding the type of media used by teachers, how teachers use digital media, as well as the reasons and barriers vocational teachers in using ICT, are described in the following discussion. Teachers 1 is a prolific teacher teaching at the course from video editing, graphic design, and photography who has over 5 years of teaching experience. He also served as a class guardian in vocational A.

Digital media type used by the Teachers 1 this many media make use of video taken from you tube and PowerPoint to give the lesson material.

Outside the classroom, (in the laboratory), he gives practice with regard to the subject matter in his hand, such as the use of photographic equipment and photo shop and CorelDraw software for image editing. Sony Vegas Pro 13 software is also used in video editing. Assignment and communication media commented on by students in Teachers 1 using online media "Edmodo" Some students give assignments via e-mail. Teachers 1 reply to comment and discuss the students' work in depth with his students Additionally, Teachers 1 also give the matter through a google form.

The reason teachers 1 prefer to use the media (PowerPoint and Video) to the material he taught for the use of power point easier and simpler to use, in PowerPoint can display slides of interest such as video displays are integrated in power point, so that students are more enthusiastic in receiving materials lesson. Teachers 1 has a Bachelor of Applied Science (S.ST) in the field of informatics. She has a high level of media dominance by having some skills in using digital media applications studied.

How to use digital media conducted by Teachers 1 did not experience significant obstacles for the teacher to teach the same age with the field.

Barriers experienced by Teachers 1 is about the infrastructure of digital media provided by schools are still lacking, although there is, specification of equipment with the demands of the industry is far from expected, so Teachers 1 provide advice to the school pay attention to the equipment of digital media in support of learning and teaching in schools. In addition Internet access is still lacking, especially going to look for teaching materials, making more use tethering Teachers 1 used through its Mobile Phones. School policies related to learning media is good enough.

Teachers 2 has a service life of 3 years. These teachers teach the subjects audio and animation techniques, positions 2 vocational teacher A teacher productive. Types of digital media used in the classroom using powerpoint, sometimes downloaded through a you tube video or animated images. If outside the class, Teachers 2 use email in the process of handover students.

Reasons Teachers 2 using power point and video in learning, because it is more easily accepted by students on using the Microsoft word displayed by InFocus, because it is tantamount to reading books and boring.

Teachers 2 power point by explaining through teachers' handbook, which is written into the power point or search the internet in accordance with the purpose or the subject matter presented. When the practice of animated lessons, teachers 2 v2.8 use blenders application, because the application is easily available and open source. Obstacles encountered in using this application is when rendering, it is enough to occupy a long time sometimes hours. There is a desire Teachers 2 wants to replace the blender applications with virtual software, only constraints on computer specifications that are not owned by the school.

Teachers 2 natural barriers in the availability of computers in the lab is limited, and computer specifications are not eligible use of the application in practice. Another obstacle is the Internet network connection constraints that are less good. School policy regarding the use of media is quite good, there 
is an attempt to add a computer school and improve the existing Internet connection.

Teachers 3 is a teachers holding certain productive subject in food culinary. Work already 2 years old. Derived of SMK B. media type used by the teachers 3 in the classroom more use of the power point, sometimes also uses a blackboard, but it is to attract the attention of students of Teachers 3 also uses instructional videos (tutorials) taken from you tube. Film also love shown by Teachers 3 goal is that learning is not saturated, the film took the course in accordance with the purpose of learning.

Outside the classroom as practice, Teachers 3 is not much use of electronic media, because its material directly related to cookware, spices etc. Unless there is a duty of students in making display their work, the students are using Mobile Phones photograph and design using computer media in lab Computer. For the design process, Teachers 3 does not have the competence, usually students with selfcontained design pictures results in the computer lab.

Electronic media such as e mail, Teachers 3 used for the delivery of student term papers into the email. Reasons Teachers 3 using a power point, because it is easy to make, and practically in the delivery of the cores of the subject matter and developed in accordance with the submitted materials.

Media chalkboard Teacher 3 sometimes use according to their needs. Teachers 3 use instructional video tutorials, to further motivate and eliminate boredom in class, because learning Teachers 3 begins at 13:00, because of the time of day as the student's condition had lazy that as his motivation sometimes played video or movie that learning. In the use of video, Teachers 3 not having problems, only occasionally to pick up the material on the internet with an internet connection is not good, it become obstacles. Sometimes using the Mobile Phones to download the video from you tube. Barriers to the use of digital media for Teachers 3 does not exist, only sometimes less good internet signal in this school. An effort that was done was to use tethering on Mobile Phones.

Teachers 4 come from SMK $\mathrm{C}$ in the access network study program, the subject of fiber optic access network, with the working period of approximately 5 years. Position the head of affairs in school infrastructure

Teachers 4 in the classroom often use instructional media using Power point, why this medium has the tools and how to use them is relatively easy. Students prefer to see the display with integrated audio and video than with the media board. In addition, Teachers 4 also uses Google's online learning media for Education (Gofed), this application is used for reasons easily done with the help of internet, teaching materials, student assignments can be done in Gofed, including online exams. Outside the classroom, the teachers 4 typically use e mail as a form of good student assignment submission form $\mathrm{g}$ mail or yahoo.

Teachers 4 using Gofed as a medium of learning outside the classroom, especially in distance learning. Tools on Gofed more iterative, intuitive with comment facilities, archiving, assignments and quizzes. Teachers 4 does not have problems using PowerPoint or integrate video and audio into a power point. But for other teachers are still many who do not know. Perhaps this is one of the obstacles the use of power point. For intermediate to expert level seem to need special training use power point. How to use Gofed for teachers must have an account official institution. Because it must be verified from the institution. Gofed can be accessed at home, lab or anywhere that is important has Internet network.

Barriers experienced teachers 4 is the use of power point still at a medium level. To explore other features need no special training to expert level. While the barriers to using Gofed is on the Internet network access, for it is very important infrastructure to provide spots of internet usage multiplied together in a particular location. To use Gofed still need for further training determines the features that are not widely known by us. Overcoming barriers to the use of these media is need for a better infrastructure, from the side of the portable PC or laptop device itself, and the need to use software that has begun all legality and need for training power point toward intermediate and expert levels.

Teachers 5 is a teacher for SMK C are the subjects of teaching is the Customer Premises Equipment (CPE) device or customer terminal tenure at the school for 5 years. Types of instructional media used by the teachers 5 in the classroom more frequent use powe point. The reason is the tools of the power full power point where the needs of different types of letters, pictures, video and audio can be integrated. Students become motivated to transform learning. Means infocus or digital TV has been prepared by the school every room is already available.

Outside the classroom, teachers 5 typically use grade virtual (online) with platform google for education (Gofed) with. GOFED is the direction of the Foundation for teachers to use as a digital means of virtual classes for students and teachers in learning. Communication with students typically use platform Line Teachers 5 for the majority of students do not use WhatsApp, so I use the same media with students.

Reasons for using a virtual classroom with GOFED apart direction of the foundation also features the ease GOFED I did a good lesson sharing 
files, assignments and quizzes can be done in GOFED. Barriers experienced in the use of learning media has been no particularly in the use of PowerPoint. While the use of GOFED must be connected to the Internet, in schools there are no obstacles internet problems, but if the student's home internet is sometimes limited to its quota.

Another obstacle for teachers is perhaps explore more about tools in PowerPoint are not fully under control, including the microsoft excel and word. This is a challenge for us. So I continue to learn, especially there is a new application. The term lifelong learning.

Technical policy of the school in SMK C related to the use of media is quite nice and the support that what is needed in learning.

Teachers 6 is a prolific teacher who taught in vocational D, Teachers 6 holds multiple productive subjects of which are subjects of Mechanical Machining Freis, Drafting with AutoCAD, Basic Machining Lathe and Machining. Teacher Position 6 in school as class guardian, working period for 2 years and 2 months.

The type of media used in the classroom Teacher 6 is familiar with the power point that contains images and text. Outside the classroom teacher 6 using media with objects directly, as if the machine by exposing the engine, engine parts and tooling in it, a rarity outside of learning using digital media unless there is a specific part of the machine then I try to download the internet and I show to students. Delivery of the form of papers usually Teacher 6 via e mail.

Reasons Teachers 6 using power point for more varied in appearance and easy to use. Students did not receive the material saturated in my show. How to use the media, Teachers 6 doesn't have problems either in operating the laptop to the projector up to a viewer for PowerPoint in the classroom.

Barriers experienced in general is in the preparation stage the media, how to summarize material into power point media, because of limited learning time, sometimes I look for material over the Internet, if the internet is not good I use Mobile Phones assistance with tethering facilities. Technical constraints no policy with school D, school support the teachers to move to existing facilities. The result of analyzing qualitative data as a whole, can be seen in table 1( appendix 1).

\section{DISCUSSION}

All vocational teachers in this study actively participate in the use of digital media learning. This study was conducted by interviewing the subjects of productive vocational teachers on the use of types of digital media in learning, the reason for the use of digital media and constraints experienced during the use of digital media in the learning process in the classroom.

On table 1 (appendix 1) can be found that vocational teachers of subjects productive in the use of media in the classroom all using the power point, outside the classroom, especially the practice of using the media activity according to subject area such as: Teachers 1 useVegas, Google Form (student test), Photoshop (student practice) Corel Draw (students practice), Teachers 2: Blender V.4 (students practice) Adobe audition (Practice students) $\mathrm{E}$ mail (in the assignment of students), Teachers 3, Teachers 4, Teachers 5 and Teachers 6, non existent application in practice of students, as they relate to employment directly deal with objects. As for the learning media to communicate both in the submission of assignments, submit items online, evaluate and comment on student assignments online: Teacher 1 use online Edmodo, e mail and Google Form, Teacher 2, Teacher 3, and Teachers 6 use using e mail, and Teachers 4 and 5 uses Google for teacher education (Gofed). Thus, this type of digital media used to use productive vocational teachers of subjects in the learning process in the classroom and outside the classroom using digital media.

The reason the use of digital media in Table 1 can be seen as follows: Teachers 1 have the following reasons: Teachers 1: Use of power point, students are more enthusiastic in accepting the subject matter; Teachers 2: Using Powerpoint more easily accepted by students on using the Microsoft word displayed by InFocus, because it is tantamount to reading books and boring; Teachers 3 states that the power point is easy to make, and practically in the delivery of the cores of the subject matter and developed in accordance with the submitted materials. And further motivate and eliminate the boredom of students in the class; Teachers 4 states that the power point has the tools and how to use a relatively easy and Students are more happy viewing with integrated audio and video than with the media board. The material presented directly get Teachers 5 Power point full power of its tools in which the needs of different types of letters, pictures, video and audio can be integrated and students become motivated to transform learning. Teachers 6 states that the power point, media is more varied in appearance and easy to use, as well as any student is not saturated in 
receiving the material that I show. Thus, it can be found the reason the use of power point in learning is when viewed from the side of the students' reasons for the use of power point is to improve the students more motivated, students do not experience boredom, not boring, and more fun. If the teacher side, a use power point reason is because it is easier to use, has the tools easy to understand and a lot of variety, such as fonts, images.

Barriers of teachers in the use of digital media from table 1 above found that: Teacher 1 reveals that digital media infrastructure provided by schools are still lacking, and internet access are also still lacking; Teacher 2:the availability of computers in the lab, which are still lacking and constraints of the Internet network connection which is not good; Teacher 3: THAT convey barrier is related to the problem internet connection is not good, so using tethering Mobile Phones; Teachers 4: States that use a power point with complicated tools still need to be explored. If you need no special training power point advanced materials; Teachers 5: experiencing barriers including not a lot of tools in PowerPoint explored and not fully under control, including the microsoft excel and word, Teachers 6: propose thatin preparing appropriate teaching materials need to summarize the points-point taught sometimes looking for teaching materialsthrough the Internet, with the Internet less good condition then use Mobile Phones assistance with tethering facilities. Thus the obstacles use the media more on Internet access, although internet facilities already exist, simply because capacity is small and not a medium to larger, then the problem is not optimal Internet access in schools, so that teachers choose the alternative using mobile technology with facilities tethering in internet usage.

All six vocational school teachers stated that school policies related to the use of digital media full support to teachers in the use of digital media, including the Internet and the provision of other facilities and infrastructures are met properly.

\section{CONCLUSION}

Our research found that six vocational school teachers were interviewed, active in using digital media in learning. School policies related to the use of digital media and the provision of infrastructure to support the use of instructional media by teachers.

Digital media type used by teachers in the classroom is the reason for the use of media power point, power point provide motivation and prevent students so as not to get bored in receiving learning materials. In addition, the integrated use of media power point audio and video. Other types of digital media vocational teachers use outside the classroom (practice) is adjusted by productive subjects. Most of the teachers have been implementing an online-based learning such as Edmodo and GOFED, and some just do not carry out the delivery of the students through email. The most common obstacles found on the Internet connection is not optimal in school.

Based on the results of this study recommended several matters related to the analysis of digital literacy vocational school teachers are:

1. Vocational school teachers must have the ability to integrate text, audio and video in digital media power point.

2. Vocational teachers should have able to cooperate and various knowledge about digital literacy especially power point media.

3. Vocational teachers should be able to use the online learning (online media) are growing rapidly in this digital era. Like Edmodo, Google for education and others.

4. School policy is an important factor in the successful development of the use of digital media.

\section{REFERENCES}

Abdelmoiz Ramadanet, al (2018). Teachers' Skills and ICT Integration in Technical and Vocational Education and Training TVET: A Case of Khartoum State-Sudan.

A. Khalkhali, S. Moradi, and F. Amuei, (2008). Assessment and Comparison of ICT' Literacy between Teachers and Students in Iran's Secondary Schools, World Appl. Sci. J., 4(3), 396-405.

Aesaert, K., Van Braak, J., Van Nijlen, D., \& Vanderlinde, R. (2015). Primary school pupils' ICT competences: Extensive model and scale development. Computers and Education, 81, 326-344.

Amy, Hutchison (2018). Using Virtual Reality to Explore Science and Literacy Concepts.

Baxa, J., \& Christ, T. (2018). The Digi Lit framework. The Reading Teacher, 71(6), 703-714.

Borg W and Gall M (1989). Educational Research: An Introduction. 5th ed. Longman. New York.

Brok, L. S. (2008). Understanding and developing "Technological Literacy" through Living Labs in teacher vocational education.

Claro, M., Preiss, D. D., San Martín, E., Jara, I., Hinostroza, J. E., Valenzuela, S., Nussbaum, M. (2012). Assessment of $21^{\text {st }}$ century ICT skills in Chile: Test design and results from high school level students. Computers and Education, 59(3), 1042-1053.

E-Safetysupport (2013) What Every Teacher Needs to Know AboutDigital Literacy. Paignton Community and Sports Academy.

Fontana A and Frokos AH (2007) The interview: From Formal to Postmodern. Left Coast Press. Walnut Creek, California.

Siddiq F., et al (2016). Taking a future perspective by learning from the paste A systematic review of 
assessment instruments that aim to measure primary and secondary school students' ICT literacy.

Göksün, D. O., \& Kurt, A. A. (2017). The relationship between pre-service teachers' use of 21 st Century learner skills and $21^{\text {st }}$ Century teacher skills. Egitimve Bilim, 42 (190), 107130.

Gruszczyska A, Merchant G, et al. (2013). Digital futures in teacher education: Exploring open approaches towards digital literacy. The Electronic Journal of $e$ learning, 11(3), 193-206.

Hague, C., and Payton, S. (2010). Digital Literacy across the Curriculum. Bristol: Futurelab.

Julien, H., and Genuis, S. (2011). Librarians' experiences of the teaching role: A national survey of librarians, Library \& Information Science Research, 33(2), 103111.

Kong, S. C. (2014). Developing information literacy and critical thinking skills through domain knowledge learning in digital classrooms: An experience of practicing flipped classroom strategy. Computers and Education, 78, 160-173.

Kubrický, J., \& Částková, P. (2015a). Teacher's Competences for the Use of Web Pages in Teaching as a Part of Technical Education Teacher's ICT Competences. Procedia-Social and Behavioral Sciences, 174, 3236-3242.

Lim HooiLian, WunThiam Yew \& Chew Cheng Meng (2014). Enhancing Malaysian Teachers' Assessment Literacy. 7(10), 74.

Lian, L. H., Yew, W. T., \&Meng, C. C. (2014). Enhancing Malaysian Teachers' Assessment Literacy. International Education Studies, 7(10). 74.

Martinovic, D., \& Zhang, Z. (2012). Situating ICT in the teacher education program: Overcoming challenges, fulfilling expectations. Teaching and Teacher Education, 28(3), 461-469.

Olofsson, A.D. Ola Lindberg, J. Fransson, Göran Hauge, T.E. (2015). Nordic Journal of Digital Literacy, 4, 207 225 .

Pe'er, S., Goldman, D., \&Yavetz, B. (2007). Environmental Literacy in Teacher Training: Attitudes, Knowledge, and Environmental Behavior of Beginning Students. The Journal of Environmental Education, 39(1), 45-59.

Panel, I.L. (2007). Digital Transformation A Framework for ICT Literacy.

Pei Zhao, Heikki Kynashlahti, Sara Sintonen. (2018). A qualitative analysis of the digital literacy of art education teachers in Chinese junior high and high schools, 50(1), pp.77-87.

Polit, D., and Beck, C. (2006). Essentials of Nursing Research: Methods, Appraisal, and Utilization. 6th edn. Lippincott Williams and Wilkins. Philadelphia,PA.
Sánchez, J., \& Salinas, A. (2008). ICT \& learning in Chilean schools: Lessons learned. Computers and Education, 51(4), 1621-1633.

UNESCO (2004). A Shift in Pedagogy and Integrating ICT into Education. UNESCO. Bangkok.

U.S. Department of Education (2001). Enhancing Education Trough Technology, SEC. 2402 - purposes and goals. Elementary and Secondary Education Act.

Wen, J. R., \& Shih, W. L. (2008). Exploring the information literacy competence standards for elementary and high school teachers. Computers and Education, 50(3), 787-806.

Zylka, J., Christoph, G., Kroehne, U., Hartig, J., \& Goldhammer, F. (2015). Moving beyond cognitive elements of ICT literacy: First evidence on the structure of ICT engagement. Computers in Human Behavior, $53,149-160$.

-2017. Materi Pendukung Literasi Digital. Gerakan literasi Digital. Kemendikbud. 


\section{APPENDIX}

Table 1: Data Analysis

\begin{tabular}{|c|c|c|c|c|}
\hline \multirow{2}{*}{$\begin{array}{c}\text { Subject/ Work period } \\
\text { (Year)/ Posotion in school }\end{array}$} & \multicolumn{2}{|c|}{ Media Type in learning } & \multirow{2}{*}{ The reason for using media in the classroom } & \multirow{2}{*}{ Barriers to the use of media } \\
\hline & In class & Outside the classroom (Practice) & & \\
\hline $\begin{array}{lrr}\text { TR1 } & \text { (Teacher } & \text { editing } \\
\text { video, } & \text { graphic } & \text { design } \\
\text { and } & \text { photograpy/ } 5 \\
\text { years/ } & \text { homeroom } \\
\text { teacher } & \end{array}$ & $\begin{array}{l}\text { Powerpoint } \text { (featuring } \\
\text { slides subjects integrated } \\
\text { with the audio / video). } \\
\text { Video tutorials (video } \\
\text { tutorial) }\end{array}$ & $\begin{array}{l}\text { Vegas (Practice editing video) } \\
\text { Edmodo online (online teachers in } \\
\text { presenting the material, evaluation } \\
\text { and comment on student } \\
\text { assignments), } \\
\text { Google Form (student test), } \\
\text { Photoshop (student practice) } \\
\text { Corel Draw (Practice students) }\end{array}$ & $\begin{array}{l}\text { The use of power point, students are more } \\
\text { enthusiastic in accepting the subject } \\
\text { matter }\end{array}$ & $\begin{array}{l}\text { digital media infrastructure provided } \\
\text { by schools are still lacking, and } \\
\text { internet access are also still lacking }\end{array}$ \\
\hline $\begin{array}{l}\text { TR2 (Teacher of audio } \\
\text { engineering } \quad \text { and } \\
\text { animation.)/ } 3 \text { years/ } \\
\text { teachers Productive }\end{array}$ & $\begin{array}{l}\text { Powerpoint (slide shown } \\
\text { in the subject matter). } \\
\text { Video tutorials. Film } \\
\text { Animation (example in } \\
\text { subjects animation) }\end{array}$ & $\begin{array}{l}\text { Blender V.4 (students practice) } \\
\text { Adobe auditon (students practice) } \\
\text { Email (in the assignment of students) }\end{array}$ & $\begin{array}{l}\text { because it is more easily accepted by } \\
\text { students on using the Microsoft word } \\
\text { displayed by InFocus, because it is } \\
\text { tantamount to reading books and boring. }\end{array}$ & $\begin{array}{l}\text { The availability of computers in the } \\
\text { lab, which are still lacking and } \\
\text { constraints of the Internet network } \\
\text { connection which is not good. }\end{array}$ \\
\hline $\begin{array}{lr}\text { TR3 (subjects of the } \\
\text { basic culinary, } \\
\text { nutrition,Hyginies } \\
\text { sanitation } & \text { and } \\
\text { entrepreneurship)/ } & 2 \\
\text { years/ Homeroom } & \\
\text { teacher } & \end{array}$ & $\begin{array}{l}\text { Powerpoint (slide show of } \\
\text { subjects), Video tutorial } \\
\text { (featuring video in food } \\
\text { processing) }\end{array}$ & Email (in the assignment of students) & $\begin{array}{l}\text { Using a power point easier to make, and } \\
\text { practically in the delivery of the cores of } \\
\text { the subject matter and developed in } \\
\text { accordance with the submitted materials. } \\
\text { And further motivate and eliminate the } \\
\text { boredom of students in the class. }\end{array}$ & $\begin{array}{l}\text { The internet connection is not good, } \\
\text { so using tethering Mobile Phones }\end{array}$ \\
\hline $\begin{array}{l}\text { TR4 (subjects of fiber } \\
\text { optic access network)/ } 5 \\
\text { years/ affairs chief } \\
\text { infrastructures }\end{array}$ & $\begin{array}{l}\text { Powerpoint is integrated } \\
\text { with audio and video } \\
\text { (featuring slides subjects) }\end{array}$ & $\begin{array}{l}\text { Google } \begin{array}{l}\text { Online for } \\
\text { (GOFED) (Gofed more }\end{array} \text { iterative, } \\
\text { intuitive with comennt facilities, } \\
\text { archiving, tasks and quizzes) }\end{array}$ & $\begin{array}{l}\text { Power point, these media have the tools } \\
\text { and how to use a easy relatively and } \\
\text { Students are more happy to see the } \\
\text { display with integrated audio and video } \\
\text { than with the media board. The material } \\
\text { presented directly get. }\end{array}$ & $\begin{array}{l}\text { The use of power point with } \\
\text { complicated tools still need to be } \\
\text { explored. If there needs to be special } \\
\text { training powerpoint advanced } \\
\text { materials. }\end{array}$ \\
\hline $\begin{array}{l}\text { TR5 (subjects of } \\
\text { Customer } \\
\text { Equipment } \\
\text { device or } \text { (CPE) } \\
\text { terminal)/ } 5 \text { customer } \\
\text { teachers Productive }\end{array}$ & $\begin{array}{l}\text { Powerpoint is integrated } \\
\text { with the audio / video } \\
\text { (featuring slides subjects) }\end{array}$ & $\begin{array}{l}\text { Google's online Class Room } \\
\text { (GOFED) (online from google, } \\
\text { teachers can manage the virtual } \\
\text { classroom, sharing materials, } \\
\text { archiving tasks, online exams and } \\
\text { comment on student assignments) }\end{array}$ & $\begin{array}{l}\text { Its Powerpoint full power tools in which } \\
\text { the needs of different types of letters, } \\
\text { pictures, video and audio can be } \\
\text { integrated and students become motivated } \\
\text { to transform learning. }\end{array}$ & $\begin{array}{l}\text { Not much to explore about the tools } \\
\text { in PowerPoint that is not fully } \\
\text { controlled by including in microsoft } \\
\text { excel and microsoft word }\end{array}$ \\
\hline $\begin{array}{l}\text { TR6 (subjects Freis } \\
\text { machining techniques, } \\
\text { technical drawing } \\
\text { autocad, rasic } \\
\text { machining lathes and } \\
\text { machining)/ } 2 \text { years/ } \\
\text { homeroom teacher }\end{array}$ & $\begin{array}{l}\text { Powerpoint (slide show of } \\
\text { subjects) }\end{array}$ & - & $\begin{array}{l}\text { more varied in appearance and easy to } \\
\text { use and Students were not saturated in } \\
\text { receiving the material that I show. }\end{array}$ & $\begin{array}{l}\text { In preparing appropriate teaching } \\
\text { materials need to summarize the } \\
\text { points taught sometimes looking for } \\
\text { teaching materials over the Internet, } \\
\text { with the Internet less good condition } \\
\text { then use Mobile Phones assistance } \\
\text { with tethering facilities. }\end{array}$ \\
\hline
\end{tabular}

